\title{
Produksi Lipid Mikroalga Laut Skeletonema sp. Hasil Kultur Massal di Outdoor Raceway Pond Sebagai Bahan Baku Biodiesel
}

\section{Lipid Production of Marine Microalga Skeletonema sp. Mass Cultivated in Outdoor Raceway Pond as Biodiesel Feedstock}

\author{
Fitrah $^{1)}$, Indrayani $^{\left.2)^{*}\right)}$, Emiyarti $^{1)}$ \\ ${ }^{1)}$ Jurusan Ilmu KelautanFakultas Perikanan dan Ilmu Kelautan \\ Universitas Halu Oleo, Kampus Hijau Bumi Tridharma, Kel. Kambu, Kec. KendariAfiliasi \\ ${ }^{2)}$ Program Studi Pendidikan Teknologi Pertanian Fakultas Teknik \\ Universitas Negeri Makassar, Kampus UNM Gunung Sari Jl. AP. Pettarani Makassar, Sulawesi Selatan, 90221 \\ Corresponding author ${ }^{*}$ : indrayani@unm.ac.id
}

\begin{abstract}
Skeletonema sp. is a marine microalgae widely studied for its potentials as a raw material for biodiesel due to fast growth, high lipid content and resistant to environmental changes. The aim of this study was to determine the specific growth rate, biomass production, lipid content and lipid productivity of a newly isolated marine microalga Skeletonema sp. mass cultivated in $1 \mathrm{~m} 2$ outdoor raceway pond. This study was conducted from June - December 2019 in the hatchery of Unit PelaksanaTeknis Daerah (UPTD) Purirono Kendari. The alga species was cultivated in $1 \mathrm{~m} 2$ raceway pond in outdoors for a month. The alga was cultured using $\mathrm{f} / 2$ medium under semi-continuous mode with harvesting time every 4 days. Sampling for cell counting was done every two days whereas sampling for biomass and lipid was conducted prior to harvesting (every 4 days). The results showed that the Skeletonema sp. can grow well in outdoor raceway ponds with an average specific growth rate of $0.30 \mathrm{~d}^{-}$ ${ }^{1}$, biomass yield of $0.62 \mathrm{~g} . \mathrm{L}^{-1}$, biomass productivity of $0.222 \mathrm{~g} . \mathrm{L}^{-1} \mathrm{~d}^{-1}$, lipid yield of $0.28 \mathrm{~g} . \mathrm{L}^{-1}$, lipid content of $44.81 \%$, and lipid productivity of $0.092 \mathrm{~g} . \mathrm{L}^{-1} \cdot \mathrm{d}^{-1}$. This study showed that the Skeletonema sp. has the potential to be developed as a raw material for biodiesel due to its high growth rate, biomass and lipid productivity when mass cultured in outdoors.
\end{abstract}

Keywords: Biodiesel, Lipids, Microalgae, Skeletonema sp.

\begin{abstract}
ABSTRAK
Skeletonema sp. adalah salah satu jenis mikroalga laut yang banyak diteliti potensi pemanfaatannya sebagai bahan baku biodiesel karena mempunyai pertumbuhan yang cepat, kandungan lipid yang tinggi serta tahan terhadap perubahan lingkungan. Penelitian ini bertujuan untuk mengetahui laju pertumbuhan spesifik, produksi biomassa, kandungan lipid, dan produksivitas lipid isolat baru Skeletonema sp. yang dikultur massal pada kolam raceway $1 \mathrm{~m} 2$ di outdoor. Pengambilan data penelitian ini dilaksanakan pada bulan Juni-Oktober 2019 di Balai Benih perikanan Unit Peleksana Teknis Daerah (UPTD) Purirono Kota Kendari. Mikroalga Skeletonema sp. di kultur massal pada kolam raceway $1 \mathrm{~m} 2$ di outdoor selama sebulan. Pengambilan sampel untuk penghitungan sel dilakukan setiap 2 hari sedangkan sampling untuk biomass dan lipid dilakukan setiap panen (4 hari sekali). Hasil penelitian menunjukan bahwa Skeletonema sp. dapat tumbuh dengan baik pada kolam raceway $1 \mathrm{~m} 2$ di outdoor dengan laju pertumbuhan spesifik rata-rata 0,30 hari $^{-1}$, biomassa yield 0,62 g.. $\mathrm{L}^{-1}$, produktivitas biomassa 0,222 g. $\mathrm{L}^{-1} \cdot \mathrm{h}^{-1}$, kandungan lipid $44,81 \%$, lipid yield $0,28 \mathrm{~g} . \mathrm{L}^{-1}$, dan produktivitas lipid $0,092 \mathrm{~g} \cdot \mathrm{L}^{-1} \cdot \mathrm{h}^{-1}$. Penelitian ini menunjukan bahwa Skeletonema sp. potensil untuk dikembangkan sebagai bahan baku biodiesel karena pertumbuhannya cepat, produktivitas biomassa dan lipid yang tinggi serta dapat dikultur massal di outdoor.
\end{abstract}

Kata Kunci: Biodiesel, lipid, mikroalga, Skeletonema sp.

DOI: http://dx.doi.org/10.33772/jsipi.v6i1.17075 


\section{PENDAHULUAN}

Kebutuhan energi dari bahan bakar minyak bumi berbasis fosil seperti solar, bensin dan minyak tanah dari masyarakat Indonesia bahkan berbagai negara di dunia dalam tahun terakhir ini mengalami peningkatan tajam. Eksploitasi secara terus-menerus terhadap bahan bakar fosil yang merupakan energi yang tidak dapat diperbaharui (unrenewable energy) mengakibatkan keberadaannya semakin menipis. Hal ini akan mengakibatkan bahan bakar fosil menjadi langka yang akan berdampak pada meningkatnya harga bahan bakar minyak (BBM) dunia. Keadaan ini telah membuat sebagian besar negara-negara di dunia salah satunya adalah Indonesia untuk mencari sumber-sumber bahan bakar alternatif yang dapat dikembangkan dari bahan dasar lain yang dapat diperbaharui dan bersifat ramah lingkungan (Kwangdinata dkk, 2013). Perkembangan bioteknologi pada masa ini telah banyak dilakukan peneliti salah satunya sumber terbarukan alternatif yang dikembangkan adalah biodiesel dengan memanfaatkan makhluk hidup yang tumbuh dan berkembang di perairan laut adalah mikroalga (Oktavianus, 2018).

Mikroalga adalah mikroorganisme yang berfotosintesis dan berkembang biak dengan cara membelah diri. Melalui proses fotosintesis mikroalga mengkonversi $\mathrm{CO} 2$ menjadi biomasa yang selanjutnya dapat dimanfaatkan untuk berbagai produk salah satunya sebagai sumber bahan baku biodiesel (Saadudin dkk, 2011). Mikroalga merupakan organisme yang memiliki potensi sebagai penghasil bahan baku biodiesel karena mempunyai kemampuan yang sangat besar untuk menghasilkan minyak alami (lipid) lebih kurang 60\% dari berat kering (Sobari dkk, 2013). Mikroala memiliki kandungan minyak mencapai $77 \%$, dimana sangat berpotensi digunakan sebagai biodiesel yang merupakan sumber energi alternatif dan berdasarkan perhitungan mikroalga mampu menghasilkan minyak 200 kali lebih banyak dibandingkan sumber nabati lainnya contohnya seperti mimyak kelapa sawit (Sumatri dkk,2014).

Mikroalga diibaratkan sebagai pabrik kecil dalam ukuran sel mikro yang mengubah karbon dioksida menjadi material potensial seperti biofuel, pangan, dan biomaterial melalui energi matahari (Hadiyanto,2012). Produktifitas minyak mikroalga termasuk Skeletonema sp. jauh lebih besar dibanding minyak yang berasal dari tumbuhan tinggi seperti kelapa sawit, minyak (lipid) yang dihasilkan mikroalga dapat mencapai sedikitnya 10 kali minyak kelapa sawit (Saadudin dkk,2011)

Skeletonema sp. merupakan mikroalga yang termasuk dalam kelas Bacillariophycea yang tidak menghasilkan racun, mudah untuk dikultur dan pertumbuhannya relatif cepat ketika dikultur massal di outdoor karena tahan akan perubahan salinitas dan intensitas cahaya yang drastis (Isnansetyo \& Kurniastuti, 1995).

Skeletonema sp. yang dikultur pada penelitian ini merupakan spesies lokal yang baru diisolasi dari perairan Kota Kendari, Sulawesi Tenggara. Hasil studi sebelumnya pada kondisi indoor menunjukkan bahwa spesies ini memiliki pertumbuhan yang cepat serta kandungan lipid yang cukup tinggi sehingga potensial untuk dikembangkan sebagai bahan baku biodiesel (Indrayani et al., 2020). Untuk dapat dimanfaatkan sebagai bahan baku biodiesel, miroalga harus mampu dikembangkan secara massal pada kondisi outdoor. Oleh karena itu, untuk mengetahui produksi biomassa dan lipid yang dapat diperoleh dari mikroalga Skeletonema sp. sebagai bahan baku alternatif pembuatan biodiesel, maka perlu dilakukan penelitian produksi lipid mikroalga Skeletonema sp. yang dikultur massal di outdoor.

\section{METODE PENELITIAN}

\section{Waktu dan tempat}

Penelitian ini dilaksanakan mulai bulan Juni Desember 2019. Penelitian ini dilakukan di Unit Pelaksana Teknis Daerah (UPTD) Balai Benih Udang Dinas Kelautan dan Perikanan, Kecamatan Purirano Kota Kendari dan di Laboratorium Pengujian Fakultas Perikanan dan Ilmu Kelautan, Universitas Halu Oleo, Kendari Sulawesi Tenggara.

\section{Spesies Mikroalga}

Spesies mikroalga yang digunakan adalah Skeletonema sp. yang diisolasi dari perairan Kendari oleh Indrayani pada tahun 2017 (Indrayani et.al 2018).

\section{Persiapan Inokulum kultur di indoor}

Skeletonema sp. dikultur di laboratorium secara bertahap untuk menyiapkan inokulum kultur sebagai starter kultur massal di outdoor. Persiapan inokulum dimulai dari kultur volume $150 \mathrm{~mL}$ lalu ke $1 \mathrm{~L}$ dan ke 10 L. Mikroalga ini di kultur menggunakan media 
12 Fitrah et al.

JURNAL SAINS dan INOVASI PERIKANAN / Journal of Fishery Science and Innovation

Vol. 6, No. 1, 10-18, Januari 2022

F/2, kultur diinkubasi pada suhu kamar dengan penerangan lampu neon dengan intensitas cahaya sekitar 100 umol. Photon.m-2.s-1 dengan siklus gelap dan terang masing-masing 12 jam.

\section{Kultur massal di outdoor}

Sebelum inokulasi di outdoor, kolam kultur massal yang berupa kolam terpal raceway dipersiapkan dengan cara dicuci dan dibersihkan dengan air laut bersih. Setelah bersih baru kemudian diisi dengan air laut yang telah disaring hingga kedalaman $10 \mathrm{~cm}$. Inokulum/starter kultur sebanyak 20 L dimasukkan secara perlahan-lahan kedalam kolam kultur. Kolam kultur selanjutnya ditambahkan air laut sampai kedalam $20 \mathrm{~cm}$. Inokulasi dilakukan pada pagi hari untuk menghindari stres akibat intensitas cahaya yang tinggi. Kultur massal di kolam raceway di outdoor dilakukan selama 1 bulan dengan metode semi-kontinyu.

\section{Ekstraksi lipid}

Ekstraksi lipid menggunakan metode Bligh and Dyer (1959)yang dimodifikasi oleh Kates and Volcani (1966). Dimana sampel sebanyak $5 \mathrm{~mL}$ difilter terlebih dahulu lalu dihancurkan kedalam tabung reaksi menggunakan batang kaca, setelah sampel hancur kemudian ditambahkan $1 \mathrm{~mL}$ larutan campuran (air + chloroform + methanol) untuk melarutkan ekstraksi lalu dipindahkan kedalam gelas tube. Kemudian tambahkan $1 \mathrm{~mL}$ larutan campuran untuk membersikan sisa ekstraksi pada tabung reaksi dan pindahkan kedalam gelas tube. Selanjutnya tambahkan 3,7 mL larutan campuran kedalam gelas tube setelah itu larutan disentrifugasi selama 20 menit pada tekanan $3000 \mathrm{rpm}$. Dimana larutan hasil sentrifugasi dipindahkan kedala gelas rube dan ditambahkan kembali larutan campuran sebanyak 5,7 $\mathrm{mL}$ lalu disentrifugasi kembali. Setalah itu sampel tersebut digabungkan kedalam gelas tube dan hasil sentrifugasi kemudian ditambahkan larutan $3 \mathrm{~mL}$ air $+3 \mathrm{~mL}$ chloroform lalu divortex agar larutan tersebut tercampur rata. Setelah itu diinkubasi selama 24 jam didalam lemari pendingin hingga terbentuk dua lapisan larutan, dimana lapisan bawah berupa lipid yang larut dalam chloroform dan lapisan atas berupa cairan air + methanol. Selanjutnya lapisan atas dikeluarkan dan lapisan bawah yang berupa lipid dipindahkan dalam gelas vial yang telah ditimbang. Chloroform pada sampel lipid dievaporasi menggunakan N2 gas dan gelas vial yang berisi lipid benar-benar kering lalu ditimbang kembali, dimana hasil dari selisih berat vial merupakan berat lipid
Metode Analysis

Penghitungan jumlah sel

Pertumbuhan kultur dimonitor dengan menghitung jumlah sel setiap 2 hari menggunakan Neubauer haemocytometer (Moheimani et al., 2013).

Menentukan laju pertumbuhan specific (Specific growth rate)

Laju pertumbuhan specific (specific growth rate $(\mu))$ dihitung menggunakan persamaan berikut:

$$
\mu=\frac{\operatorname{Ln}\left(N_{2} / N_{1}\right)}{t_{2}-t_{1}}
$$

Menentukan berat kering biomass (Dry weight (DW) dan berat kering organic (ash free dry weight (AFDW))

Dimana penetuan DW dan AFDW mengacu pada standar metode untuk mengukur pertumbuhan microalgae (Moheimani et al., 2013):

$$
D W\left(\text { g. } L^{-1}\right)=W 2-W 1
$$

Dimana:DW= Berat kering biomassa

$\mathrm{W} 2=$ Berat kertas saring + alga

$\mathrm{W} 1=$ Berat kertas saring

Filter kemudian dipindahkan ke oven furnace pada suhu 450oC selama 5 jam. Berat kering oganic (Ash-free dry weight) dihitung menggunakan formula berikut:

\section{$A F D W\left(g . L^{-1}\right)=D W-$ Berat $a b u$ \\ Produktivitas biomassa (PB)}

Produktifitas biomassa dihitung menggunakan persamaan berikut:

$$
P B\left(\text { g. } L^{-1} \cdot L^{-1} \cdot \text { Hari }^{-1}\right)=\mu x A F D W
$$

Dimana: $\mathrm{PB}=$ Produktifitas biomassa

$$
\mu=\text { Laju pertumbuhan }
$$

Total Lipid (Lipid Yield (LY))

Total lipid dihitung menggunakan persamaan berikut:

Total lipid $\left(\right.$ g. $\left.L^{-1}\right)=($ Berat viat + lipid alga $)-$ Berat vial

Produktivitas Lipid (PL)

Produktivitas lipid (g. $\mathrm{L}^{-1}$ ) dihitung menggunakan persamaan berikut:

$$
\text { Produktivitas lipid }\left(\text { g. } L^{-1} . \text { hari }^{-1}\right)=\mu x \text { Total lipid }
$$

Dimana: PL $=$ Produktivitas lipid

$\mu=$ Laju Pertumbuhan

\section{HASIL DAN PEMBAHASAN}

\section{Hasil}

Pertumbuhan Skeletonema sp.

Hasil perhitungan sel mikroalga laut skeletonema sp. selama masa kultur kurang lebih sebulan pada kolam raceway di outdoor dengan mode semikontinyu dapat dilihat pada Gambar 1. Pada 
gambar tersebut terlihat bahwa mikroalga dapat tumbuh dengan baik selama masa periode kultur. Pada awal inokulasi dengan kepadatan sel sekitar 92 x $10^{4}$ sel.mL $\mathrm{mL}^{-1}$ hingga hari ke 4 kepadatan sel mengalami peningkatan yang cukup cepat mencapai $190 \times 10^{4}$ sel. $\mathrm{mL}^{-1}$ dan mulai berkurang pada saat memasuki hari ke 6 yang ditandai dengan awal fase stationer. Saat memasuki fase stationer, kultur dipanen sebagian (50\%) kemudian ditambahkan media kultur yang baru serta diberikan nutrient yang sesuai dosis dan dibiarkan tumbuh hingga 2-4 hari baru kemudian dipanen hingga seterusnya selama masa periode kultur. Kepadatan sel tertinggi diperoleh pada hari ke 5 dan 20 dengan kepadatan sel mencapai 499-570 x $10^{4}$ sel.mL ${ }^{-1}$.

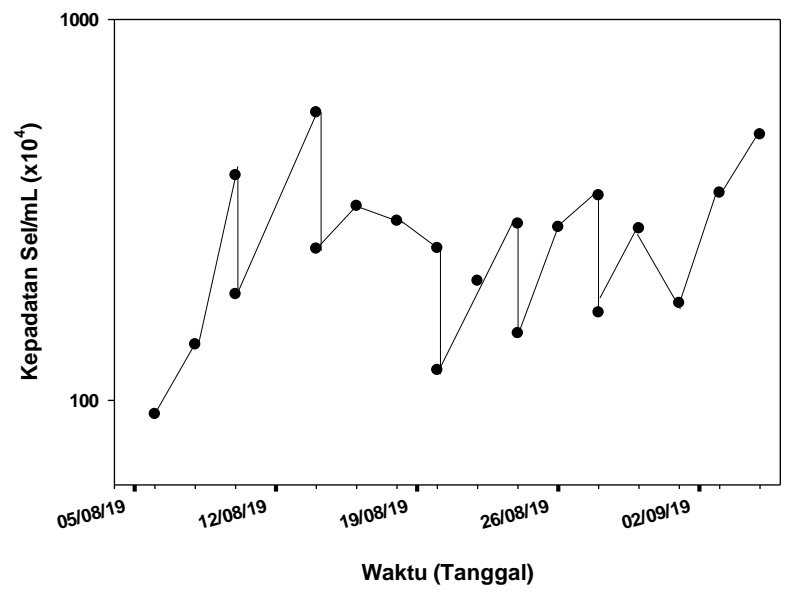

Gambar 1. Kurva Pertumbuhan Skeletonema sp. Pada Kolam Raceway $1 \mathrm{~m}^{2}$ di outdoor.

Hasil analisis laju pertumbuhan spesifik mikroalga laut skeletonema sp. selama periode kultur pada kolam raceway di outdoor dapat dilihat pada Gambar 2. Hasil analisis menujukkan laju pertumbuhan spesifik skeletonema sp. tertinggi diperoleh pada panen ke 2 dengan nilai 0,55/hari dan nilai terendah pada panen ke 3 dengan nilai 0,13 /hari dengan demikian diperoleh nilai rata-rata laju pertumbuhan spesifik skeletonema sp. yaitu 0,30/hari (Gambar 2).

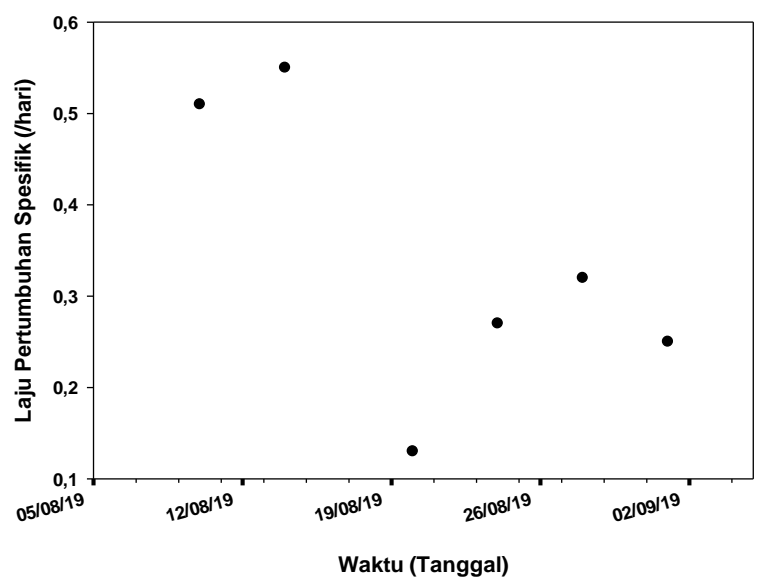

Gambar 2.Laju pertumbuhan spesifik (/hari)

Skeletonema sp. yang dikultur massal pada kolam raceway $1 \mathrm{~m}^{2}$ di outdoor.

\section{Yield Biomassa dan Produktivitas Biomassa Skeletonema sp.}

Hasil analisis yield biomassa skeletonema sp. yang dikultur massal di outdoor pada kolam raceway $1 \mathrm{~m}^{2}$ menunjukkan nilai yield biomassa tertinggi terdapat pada saat panen ke 6 dengan nilai yield biomassanya yaitu $0,82 \mathrm{~g} / \mathrm{L}$ dan nilai yield terendah terdapat pada panen ke 5 dengan nilai yield biomassanya yaitu $0,29 \mathrm{~g} / \mathrm{L}$ dengan diperoleh nilai rata-rata yield biomassa dengan nilai $0,62 \mathrm{~g} / \mathrm{L}$ (Gambar 3).



Gambar 3. Biomass yield (g/L) Skeletonema sp. yang dikultur massal pada kolam raceway $1 \mathrm{~m}^{2} \mathrm{di}$ outdoor. 
14 Fitrah et al.

JURNAL SAINS dan INOVASI PERIKANAN / Journal of Fishery Science and Innovation Vol. 6, No. 1, 10-18, Januari 2022

Produktivitas biomassa skeletonema sp. diperoleh nilai tertinggi yaitu $0,412 \mathrm{~g} / \mathrm{L} / \mathrm{h}$ pada saat panen ke 2 dan terendah dengan nilai yaitu $0,049 \mathrm{~g} / \mathrm{L} / \mathrm{h}$ pada saat panen ke 3 dengan nilai rata-rata produksivitas biomassa sebesar yaitu 0,222 $\mathrm{g} / \mathrm{L} / \mathrm{h}$ (Gambar 4).

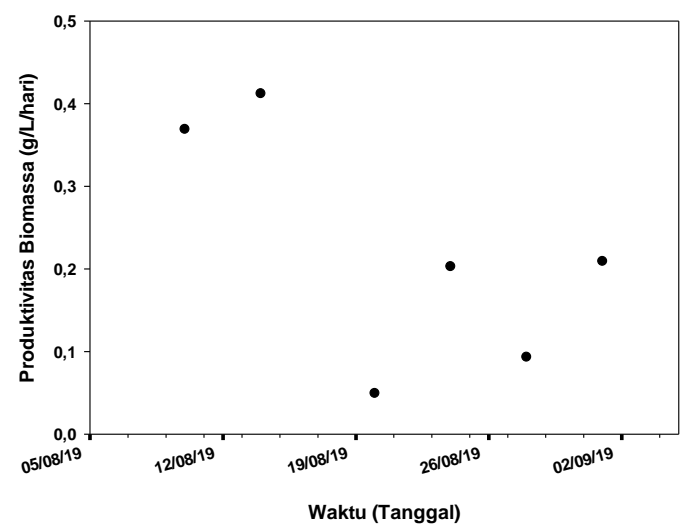

Gambar 4. Produktivitas biomassa (g/L/hari) Skeletonema sp. yang dikultur massal pada kolam raceway $1 \mathrm{~m}^{2}$ di outdoor.

\section{Lipid Yield, Lipid Content dan Produktivitas Lipid Skeletonema sp.}

Hasil analisis lipid yield Skeletonema sp. yang dikultur massal secara outdoor pada kolam raceway 1 $\mathrm{m}^{2}$ menunjukkan nilai lipid yield tertinggi terdapat pada saat panen ke 4 dengan nilai lipid yield yaitu $0,36 \mathrm{~g} / \mathrm{L}$ dan nilai lipid yield terendah terdapat pada panen ke 5 dengan nilai lipid yield yaitu 0,16 $\mathrm{g} / \mathrm{Ldengan}$ nilai rata-rata lipid yield yaitu $0,28 \mathrm{~g} / \mathrm{L}$ (Gambar 5).

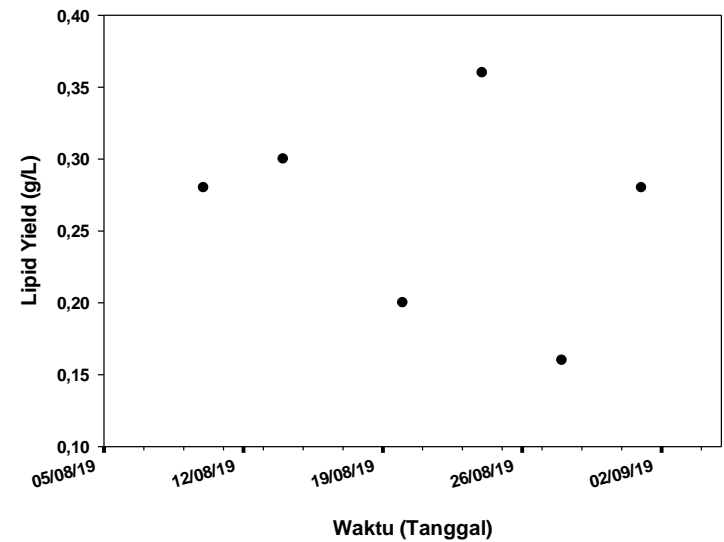

Gambar 5. Lipid yield (g/L) Skeletonema sp. Yang dikultur massal pada kolam raceway $1 \mathrm{~m}^{2}$ di outdoor.
Kandungan lipid Skeletonema sp. yang dikultur massal secara outdoor pada kolam raceway $1 \mathrm{~m}^{2}$ menunjukkan nilai lipid tertinggi yaitu $55,17 \%$ dan nilai terendah yaitu $34,15 \%$ dengan rata-rata kandungan lipid yang diperoleh adalah $44,81 \%$ (Gambar 6).

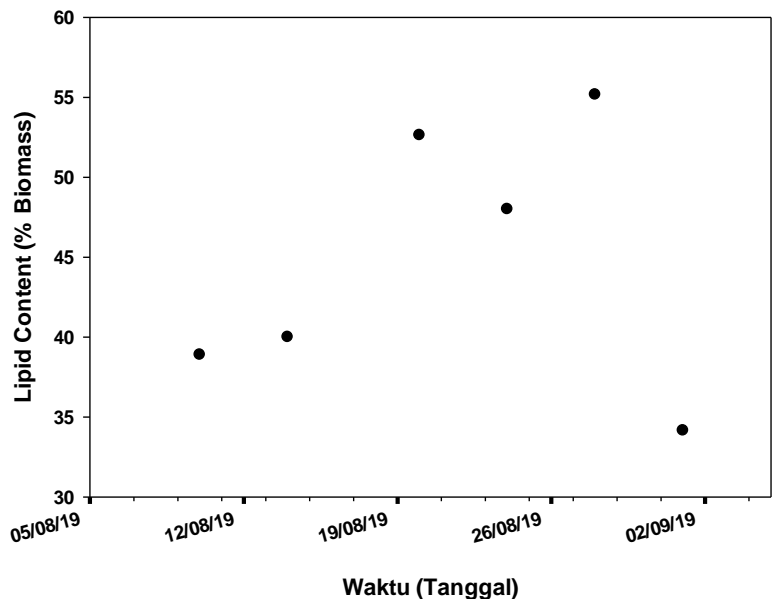

Gambar 6. Lipid content (\% Biomass) Skeletonema sp. yang dikultur massal pada kolam raceway $1 \mathrm{~m}^{2} \mathrm{di}$ outdoor.

Produktivitas lipid Skeletonema sp. diperoleh nilai tertinggi yaitu $0,165 \mathrm{~g} / \mathrm{L} / \mathrm{h}$, pada saat panen ke 2 dan terendah dengan nilai yaitu $0,025 \mathrm{~g} / \mathrm{L} / \mathrm{h}$ pada saat panen ke 3 dengan nilai rata-rata yaitu $0,092 \mathrm{~g} / \mathrm{L} / \mathrm{h}$ (Gambar 7).



Gambar 7. Produktivitas lipid (g/L/h) Skeletonema sp. yang dikultur massal pada kolam raceway $1 \mathrm{~m}^{2} \mathrm{di}$ outdoor. 
Vol. 6, No. 1. 10-18, Januari 2022

\section{Hubungan Laju Pertumbuhan Spesifik dan Produktivitas Lipid}

Hasil penelitian menunjukkan bahwa laju pertumbuhan spesifik mikroalga laut Skeletonema sp. dan produktivitas lipid memiliki korelasi yang kuat dimana semakin tinggi laju pertumbuhan maka semakin tinggi pula produktivitas lipid (Gambar 8).

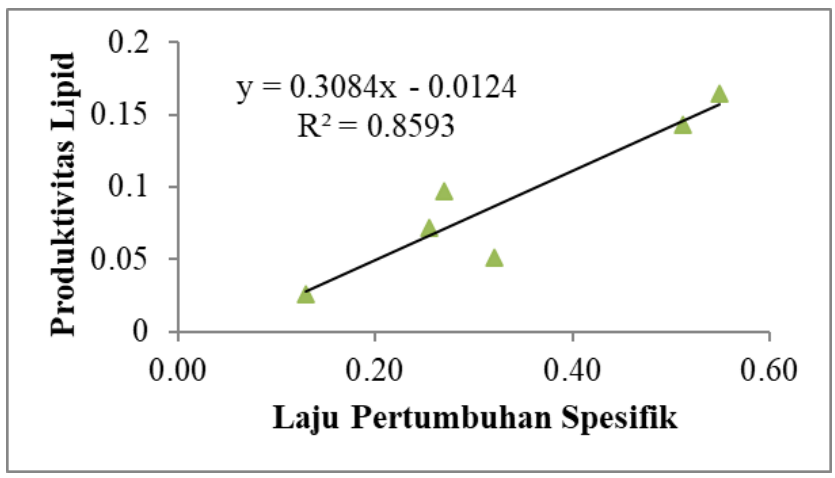

Gambar 8. Hubungan Antara Laju Pertumbuhan Spesifik dan Produktivitas Lipid Skeletonema sp.

\section{Pembahasan}

Hasil penelitian menunjukan bahwa Skeletonema sp. dapat tumbuh dengan baik saat dikultur massal pada kolam raceway $1 \mathrm{~m}^{2}$ di outdoor. Secara umum Skeletonema sp. menunjukan pertumbuhan yang bagus selama satu bulan periode kultur meskipun kecepatan pertumbuhannya bervariasi, dimana ada saat kepadatan sel dan laju pertubuhan spesifik sangat tinggi dan ada pula pada saat kepadatan sel dan laju pertumbuhan spesifik menurun. Perbedaan kecepatan pertumbuhan mikroalga ini disebabkan faktor lingkungan seperti perubahan cuaca yang tak menentu yang terjadi selama masa kultur dilakukan. Dimana intensitas cahaya sangat mempengaruhi laju pertumbuhan spesifik Skeletonema sp. karena semakin tinggi intensitas cahaya makan semakin baik juga laju pertumbuhan spesifik Skeletonema sp. begitu pun sebaliknya dengan produktivitas biomassanya, apabila intensitas cahaya matahari berkurang maka laju pertumbuhan spesifik dan produktivitas biomassanya akan semakin rendah dan berkurang akibat dari faktor cuaca yang tidak mendukung karena mendung dan hujan sehingga tidak dapat melakukan proses fotosintesis secara optimal yang mengubah energi matahari menjadi energy kimia yang disimpan dalam bentuk senyawa organik. Hal ini sesuai dengan pernyataan Armanda (2013) yang menyatakan bahwa intensitas cahaya matahari yang berlebihan akan menghambat laju pertumbuhan sepesifik dan produktifitas biomassa begitu juga sebaliknya apabila intensitas cahaya matahari berkurang akibat cuaca hujan deras, dan mendung maka suhu menjadi rendah akibatnya memperlambat pertumbuhan mikroalga yang akan berdampak pada produktifitas biomassanya, dimana intensitas cahaya matahari dan suhu erat kaitannya. Oleh karena itu, pentingnya melakukan peninjauan tempat atau wilayah terlebih dahulu sebelum melakukan pengulturan massal mikroalga agar dapat mengoptimalkan penggunaan intensitas cahaya matahari yang maksimum dengan intensitas curah hujan yang rendah (Indrayani et al., 2020).

Dari hasil kultur massal mikroalga Skeletonema sp. diperoleh nilai rata-rata laju pertumbuhan spesifik Skeletonema sp. yaitu $0,30 / \mathrm{h}$. Nilai laju pertumbuhan spesifik yang diperoleh pada penelitian ini sebanding dengan hasil yang diperoleh Dewi (2017) dengan jenis mikroalga laut yang diteliti adalah Thalassiosira sp. dan mendapatkan laju pertumbuhan spesifik yaitu $0,40 / \mathrm{h}$, penelitian yang dilakukan Indrayani et al., (2020) dengan jenis mikroalga laut yang diteliti adalah Skeletonema sp.UHO29 dan mendapatkan laju pertumbuhan spesifik yaitu $0,56 / \mathrm{h}$ pada kondisi indoor. Diatom Amphora sp. MUR 258 yang dikultur pada kolam raceway di outdoor di Perth Australia memiliki laju pertumbuhan spesifik 0,29/h (Indrayani et al. 2019). Sedangkan pada kondisi indoor, Amphora sp. MUR 258 memiliki laju pertumbuhan spesifik 0,61/h (Indrayani et al, 2020). Perbedaan nilai yang diperoleh dapat disebabkan oleh perbedaan spesies/strain yang digunakan serta kondisi kultur.

Kondisi lingkungan di outdoor sangat mempengaruhi pertumbuhan Skeletonema sp. Faktor faktor lingkungan selain intensitas cahaya yang juga mempengaruhi pertumbuhan kultur Skeletonema sp. adalah suhu dan salinitas, dimana suhu dan salinitas merupakan faktor lingkungan yang berhubunan erat dengan intensitas cahaya matahari. Pada saat panas/terik intensitas cahaya matahari tinggi maka suhu media kultur akan lebih tinggi dibandingkan saat cuaca mendung/hujan. Demikian juga dengan salinitas, intensitas matahari yang tinggi selama berhari-hari akan meningkatkan penguapan media kultur sehingga salinitas media kultur akan meningkat secara perlahan-lahan. Sebaliknya curah hujan yang terus-menerus akan menurutkan kadar salinitas media kultur akibat pengenceran oleh hujan. Pada penelitian diperoleh kisaran suhu $25^{\circ} \mathrm{C}-31^{\circ} \mathrm{C}$ 
16 Fitrah et al.

JURNAL SAINS dan INOVASI PERIKANAN / Journal of Fishery Science and Innovation Vol. 6, No. 1, 10-18, Januari 2022

kultur dan salinitas berkisar 36-38 ppt. Nilai kisaran suhu dan salinitas yang diperoleh tidak terlalu besar dan masih berada dalam kisaran suhu dan salinitas optimal bagi pertumbuhan mikroalga laut Skeletonema sp. dimana suhu dan salinitas optimal pada mikroalga laut Skeletonema sp. dapat hidup pada kisaran suhu $25^{\circ} \mathrm{C}-30^{\circ} \mathrm{C}$ (Rudiyanti, 2011). Sedangkan (Isnansetyo dan Kurniastuti, 1995) salinitas yang optimal untuk pertumbuhan Skeletonema sp.berkisar antara 28-35\% (Isnansetyo \& Kurniastuti, 1995).

Pada pertengahan bulan Agustus dilokasi peneltian cuaca cerah sehingga intensitas cahaya matahari tinggi yang berdampak pada peningkatan laju pertumbuhan Skeletonema sp. namun pada akhir bulan Agustus intensitas cahaya berkurang akibat dari perubahan cuaca yang tidak menentu (mendung dan hujan) sehingga mengakibatkan laju pertumbuhan Skeletonema sp. menjadi rendah yang berdampak terhadap rendahnya nilai produktivitas biomassa. Hal ini sesuai dengan pernyataan Moheimani et al.,(2013) bahwa jumlah produktivitas biomassa mikroalga erat kaitannya dengan laju pertumbuhan dan yield biomassa, dimana laju pertumbuhan dan yield biomassa memiliki jumlah yang tinggi maka produktivitas biomassanya juga tinggi namun sebaliknya jika salah satunya rendah maka produktifitas biomassanya juga rendah.

Lipid yield yang didapatkan pada mikroalga laut Skeletonema sp. tertinggi berkisar $(0,36 \mathrm{~g} / \mathrm{L})$, dimana nilai yang diperoleh lebih tinggi dibandingkan penelitian lainnya yang pernah dilakukan oleh Indrayani et al.,(2020) dengan mendapatkan lipid yield yaitu $(0,175 \mathrm{~g} / \mathrm{L})$. Perbedaan nilai lipid yield yang diperoleh dapat disebebkan oleh perbedaan kondisi kultur. Studi yang dilakukan oleh Indrayani et al., (2020) dilakukan di indoor dengan intensitas cahaya yang lebih rendah sedangkan pada penelitian ini dilakukan pada pada kolam raceway di outdoor dengan intensitas cahaya yang lebih tinggi sehingga akan berpengaruh terhadap produksi biomassa maupun lipid.

Pada tanggal 10 Agustus 2019 terjadi peningkatan total produksi lipid Skeletonema sp. dikarenakan cuaca pada saat itu mendukung, dimana intensitas cahaya matahari yang tinggi dan suhu air laut pada bak kultur menjadi tinggi sehingga produksi lipidnya pada mikroalga Skeletonema sp. meningkat. Sedangkan produksi lipid yang terendah terjadi pada tanggal 20 Agustus 2019 dimana kondisi cuaca tidak mendukung akibat mendung/hujan. Hal ini sesuai dengan pernyataan Renaud et al.,(2002); Chen., (2012); Pasquet et al., (2014); Al-Hasan et al., (1990) yang menyatakan bahwa suhu dan salinitas merupakan faktor yang sangat mempengaruhi pertumbuhan mikroalga, suhu dapat mempengaruhi kualitas lipid dan kandungan lipid meningkat dengan meningkatnya salinitas. Dimana suhu dapat mempengaruhi proses fotosintesis, proses metabolisme dan respirasi serta perubahan suhu juga dapat mempengaruhi kecepatan dekomposisi bahan organik dan kadar salinitas yang berubah ubah dapat menghabat aktivitas sel dari Skeletonema sp.

Hasil penelitian kami menunjukan kandungan lipid Skeletonema sp. yang tinggi mencapai 55,17\%. Nilai kandungan lipid yang diperoleh pada penelitian ini lebih tinggi dibandingkan hasil yang diperoleh oleh peneliti lain. Penelitian lain yang dilakukan oleh Indrayani et al., (2020) dengan jenis mikroalga laut yang diteliti adalah Skeletonema sp.UHO29 dan mendapatkan kandungan lipid yaitu $28,78 \%$. Sharmin dkk, (2016) melakukan penelitian tentang Skeletonema costatum dipantai Bangladesh dan mendapatkan kandungan lipid yaitu 15,37\%. Laurenco dkk, (2002) melakukan penelitian tentang Skeletonema costatum mendapatkan kandungan lipid yaitu 13,18\% dan Chen, (2012) melakukan peneltian tentang Skeletonema costatum dan mendapatkan kandungan lipid 36,90\% hingga 41,42\%. Perbedaan nilai lipid yang diperoleh dapat disebabkan oleh beberapa faktor diantaranya perbedaan spesies/strain yang digunakan, kondisi kultur serta lokasi penelitian yang dilakukan oleh masing-masing peneliti (Hernandi dkk, 2019).

Produktivitas lipid pada mikroalga laut Skeletonema sp. tergantung pada laju pertumbuhan dan lipid dari mikroalga laut Skeletonema sp. Hubungan antara laju pertumbuhan spesifik dan produktivitas lipid mikroalga Skeletonema sp. menunjukkan bahwa laju pertumbuhan sangat berpengaruh terhadap produktivitas lipid mikroalga Skeletonema sp. Semakin tinggi laju pertumbuhan spesifik mikroalga Skeletonema sp. maka semakin tinggi pula produktivitas lipidnya. Hal ini sesuai dengan pernyataan Moheimani et al., (2013) yang menyatakan bahwa total produkvitas lipid mikroalga merupakan hasil dari perkalian dari laju pertumbuhan spesifik dan lipid yield mikroalga, apabila laju pertumbuhan dan lipid yield mikroalga tinggi maka produktivitas mikroalga Skeletonema sp. juga akan 
tinggi. Namun, apabila laju pertumbuhan atau lipid yield Skeletonema sp. rendah maka produktivitas lipid dan Skeletonema sp. juga akan rendah.

\section{KESIMPULAN DAN SARAN}

\section{Kesimpulan}

Berdasarkan hasil penelitian dapat disimpulkan beberapa hal diantaranya sebagai berikut:

1. Mikroalga laut Skeletonema sp. dapat tumbuh dengan baik saat dikultur massal pada kolam raceway $1 \mathrm{~m}^{2}$ di outdoor dimana laju pertumbuhan spesifik Skeletonema sp. selama periode kultur massal di outdoor pada kolam receway $1 \mathrm{~m}^{2}$ berkisar 0,13/hari - 0,55/hari dengan rata-rata $0,30 /$ hari.

2. Biomass yield Skeletonema sp. selama periode kultur massal di outdoor pada kolam receway 1 $\mathrm{m}^{2}$ berkisar $0,29 \mathrm{~g} / \mathrm{L}-0,82 \mathrm{~g} / \mathrm{L}$ dengan rata-rata $0,62 \mathrm{~g} / \mathrm{L}$.

3. Lipid content Skeletonema sp. selama periode kultur massal di outdoor pada kolam receway 1 $\mathrm{m}^{2}$ berkisar $34,15 \%-55,17 \%$ dengan rata-rata $44,81 \%$.

4. Produktivitas lipid Skeletonema sp. selama periode kultur massal di outdoor pada kolam receway $1 \mathrm{~m}^{2}$ berkisar $0,025 \mathrm{~g} / \mathrm{L} / \mathrm{h}-0,165 \mathrm{~g} / \mathrm{L} / \mathrm{h}$ dengan rata-rata $0,092 \mathrm{~g} / \mathrm{L} / \mathrm{h}$.

5. Skeletonema sp. potensi untuk digunakan sebagai bahan baku biodiesel karena pertumbuhannya yang cepat, kandungan lipid dan produktivitas lipid yang tinggi saat dikultur massal pada kolam raceway di outdoor.

\section{Saran}

Perlu adanya penelitian lanjutan untuk mengoptimalkan produktivitas biomassa dan lipid Skeletonema sp. dangan memperhatikan beberapa hal pada saat kondisi outdoor diantaranya media kultur, waktu pengenceran (panen), dan kedalaman kultur.

\section{DAFTAR PUSTAKA}

Al Hasan RH, Ali AM, Hana H, Ridwan SS. 1990. Effect of Salinity on the Lipid and Fatty Acid Composition of the Halophyte Navicula sp.: Potential in Mariculture. J Appl Phycol. 2:215222.

Armanda, D. T. 2013. Pertumbuhan Kultur Mikroalga Diatom Skeletonema costatum
(Greville) Cleve Isolat Jepara pada Medium F2 dan Medium Conway.Bioma.Vol. 2(1). Hal: 4963.

Bligh EG, Dyer WJ. 1959. Metode Cepat Ekstraksi Lipid Total dan Pemurnian. Can J Biochem Physiol. 37: 911-917.

Chen YC. 2012. Biomassa dan Kandungan Lemak Total dan Komposisi Dua Belas Spesies Diatom Laut Dibudidayakan dengan Berbagai Macam Lingkungan. Kimia Makanan. 131: 211-219.

Hadiyanto \& Maulana, A. 2012.Mikroalga Sumber Pangan dan Energi Masa Depan. Upt Undip Press Semarang, Semarang.

Hernandi, R. Abdi, D. \& Armaini A. 2019. Penapisan, Isolasi, dan Karakterisasi Mikroalga yang Berpotensi Sebagai Sumber Biodiesel dari Perairan Danau Kerinci, Jambi. Jurnal Litbang Industri. Vol. 9(1). Hal: 41-49.

Indrayani., Haslianti., Asriyana. 2018. Isolation and screening of marine microalgae from Kendari waters,Southeast Sulawesi, Indonesia suitable for outdoor mass cultivation in hypersaline media. AACL Bioflux 11(5),1445-1455.

Indrayani, Haslianti, Asmariani, Wellem H., M uis B. 2020. Growth, Biomass and Lipid Productivity of a Newly Isolated Tropical Marine Diatom, Skeletonema sp. UHO29, Under Different Light Intensities. Biodiversitas 21(4): 1498-1503.

Indrayani, I., Moheimani, N.R., Borowitzka, M.A. 2019. Long-term reliable culture of a halophilic diatom, Amphora sp.MUR258, in outdoor raceway ponds. J. Appl. Phycol. 31:2771-2778. DOI 10.1007/s 10811-019-01803-y

Indrayani, I., Moheimani, N. R., de Boer, K., Bahri, P.A., Borowitzka, M.A. 2020. Temperature and salinity effects on growth and fatty acid composition of a halophilic diatom, Amphora sp. MUR258 (Bacillariophyceae). J. Appl. Phycol. 32:977-987. Doi 10.1007/s10811-020-02053-z.

Isnansetyo, A. dan Kurniastuti. 1995. Teknik Kultur Fitoplankton dan Zooplankton Pakan Alami untuk Organisme Laut. Kanisius. Yogyakarta. Hal 36-52.

Kates M, Volcani BE. 1966. Komponen Lipid Diatom. Biochim Biophys Acta. 116: 264-278.

Kwangdinata, R., Indah, R., Muhammad, Z. 2013. Produksi Biodiesel dari Lipid Fitoplankton Nannochloropsis sp. Melalui Metode Ultrasonik.Marine Chimica Acta.Vol. 14(2). Hal: 28-36. 
18 Fitrah et al.

JURNAL SAINS dan INOVASI PERIKANAN / Journal of Fishery Science and Innovation

Vol. 6, No. 1, 10-18, Januari 2022

Laurenco SO, Barbarino E, Manchini-Filho J, Schinke KP, Aidar E. 2002. Effects of different nitrogen sources on the growth and biochemical profile of 10 marine microalgae in batch culture: An evaluation for aquaculture. Phycologia; Abingdon 41 (2): 158-168.

Moheimani N., R., Borowitzka M., A., Isdepsky A., Fon Sing S., 2013 Standard methods for measuring growth of algae and their composition. In: Borowitzka MA, Moheimani NR (eds) Algae for biofuels and energy. Springer, Dordrecht, pp 265-284.

Oktavianus, S. G. 2018. Mikroalga: Sumber Energi Terbarukan Masa Depan. Jurnal Kelautan. Vol. 11(1). Hal: 96-103.

Pasquet V, Ulmann L, Mimouni V, Guiheneuf F, Jacquette B, Moront-Manceau A, Tremblin G. 2014. Fatty Acid Profile and Temperature in the Cultured Marine Diatom Odontella aurita. J Appl Phycol. 26:2265-2271.

Renaud SM, Thint L-V, Lambrinidis G, Parry DL. 2002. Effen of Tempereture on Growth, Chemical Composition and fatty Acid Composition of Tropical Australian Microalgae Grown in Batch Cultures. Aquaculture. 211:195214.

Saadudin. E., Silvy.R.F., Verina, J.W. 2011. Karakteristik Asam Lemak Mikroalga Untuk Produksi Biodiesel. Jurnal Ketenaga Listrikan dan Energi Terbarukan.Vol. 10(2). Hal: 131-140.

Sharmin T, Md Chowdhury, Hasan M, Aftabuddin S, Rahman Md.A, Khan M. 2016. Pertumbuhan, Asam Lemak, dan Komposisi Lipid Ikan Laut Mikroalga Skeletonema costatum Tersedia di Pantai Bangladesh: Pertimbangan Sebagai Bahan Baku Biodiesel. J Mar Sci. Doi: 10.1155/2016/6832847.

Sobari, R., AB Susanto., Dwi. S., Dellcia. Y.R. 2013. Kandungan Lipid Beberapa Jenis Sionobakterial Laut Sebagai Sumber Penghasil Biodiesel. Vol. 2(1). Hal: 112-119.

Sumatri, I., dan Hardiyanto, S. 2014. Produksi Biomasa Mikroalga dengan Nitrifikasi Limbah Beramoniak Tinggi.Vol. 10(2). Hal: 1-6. 